\title{
Exacerbations of Severe Asthma While on Anti-IL-5 Biologics
}

\author{
Bhalla $A^{1 *}$, Zhao $N^{1 *}$, Rivas $D^{2}$, Ho $T^{1}$, Perez de Llano $L^{2}$, Mukherjee $M^{1}$, Nair $\mathrm{P}^{1}$ \\ 'Firestone Institute for Respiratory Health, St Joseph's Healthcare \& Department of Medicine, McMaster University, Hamilton, Ontario, Canada \\ 2Department of Respiratory Medicine, Lucus Augusti University Hospital, EOXI, Lugo Cervo, Monforte, Spain \\ *Both authors contributed equally.
}

J Investig Allergol Clin Immunol 2020; Vol. 30(5): 307-316

doi: 10.18176/jiaci.0628

\begin{abstract}
Anti-interleukin 5 (IL-5) and anti-IL-5 receptor $\alpha$ monoclonal antibodies markedly decrease airway and peripheral blood eosinophil numbers and are thus highly effective in reducing asthma exacerbations. Nonetheless, these biologics do not completely resolve exacerbations. There is very little information on the cellular nature of exacerbations during treatment with biologics. Using illustrative clinical case scenarios, we highlight the importance of carefully characterizing asthmatics at the time of exacerbation and recognizing neutrophilic causes of exacerbations to ensure optimal management. While an eosinophilic exacerbation may improve with more corticosteroids or by switching to another anti-IL-5 monoclonal antibody, a noneosinophilic exacerbation will likely not. An infective exacerbation needs to be recognized, and the pathogen must be identified and treated with the appropriate antimicrobial agent.
\end{abstract}

Key words: Severe asthma. Exacerbations. Anti-IL5 biologics. Sputum cell counts. Airway infections. Eosinophils.

\section{Resumen}

Los anticuerpos monoclonales anti-interleucina 5 (IL5) y anti-receptor de IL5 son altamente efectivos en reducir las exacerbaciones del asma al disminuir notablemente el número de eosinófilos en las vías respiratorias y en sangre periférica. Sin embargo, aun estando bajo el tratamiento con estos biológicos, las descompensaciones asmáticas no desaparecen por completo. Disponemos de una modesta evidencia que señala la naturaleza de estas exacerbaciones, y los pacientes afectos de asma grave en estas terapias podrían tener exacerbaciones graves no eosinofílicas. Utilizando como escenarios ilustrativos varios casos clínicos, destacamos la importancia de caracterizar cuidadosamente al paciente asmático en el momento de la exacerbación y reconocer las causas neutrofílicas de las exacerbaciones, lo cual es de importancia a la hora de manejar estas exacerbaciones. Si bien una exacerbación eosinofílica puede beneficiarse con más glucocorticosteroides 0 al cambiar a otro mAb anti-IL5, una exacerbación no eosinofílica probablemente no lo hará. Es necesario reconocer una exacerbación infecciosa, identificar el patógeno y tratarlo con el agente antimicrobiano más apropiado.

Palabras clave: Asma grave. Exacerbación. Biológicos anti-IL5. Recuento celular en esputo. Infecciones de la vía área. Eosinófilos. 


\section{Introduction}

Antieosinophilic biologics are changing the landscape of severe asthma treatment, particularly in patients with severe asthma characterized by a type 2 high inflammatory signature, where monoclonal antibodies (mAbs) have demonstrated significant improvements in symptoms, quality of life, lung function, exacerbation frequency, and corticosteroid dependence $[1,2]$. Long-term monitoring shows that these mAbs, which deplete circulating and tissue eosinophils, are well-tolerated with minimal adverse effects [3-5]. Traditionally, eosinophils have been considered key effector cells against helminth infections and are associated with allergic diseases. However, there is mounting evidence that eosinophils are also intimately involved in innate host defense [6,7]. The Local Immunity And/or Remodeling/ Repair (LIAR) hypothesis suggests that resident tissue eosinophils ensure local homeostasis and remodeling in areas where there are complex and dynamic immune reactions [8]. This is especially true for tissues with a high degree of cell proliferation or where there is significant interface with the environment, such as the gastrointestinal tract, the uterus and, to some degree, the respiratory tract [8]. As such, eosinophilic depletion may potentially lead to immune dysregulation in susceptible individuals, and infections may occur as a collateral consequence of eosinophil suppression. In this review, we present a series of 4 patients who developed atypical or serious airway infections (many leading to exacerbations) while being treated with antieosinophil biologics. We discuss potential mechanisms that may lead to susceptibility to infections, including the potential role of eosinophils in host defense. These cases also highlight the importance of considering noneosinophilic exacerbations in patients on anti-IL-5 therapies before switching between biologics (Tables 1 and 2).

\section{Anti-IL-5 Biologics and Asthma Exacerbations}

Although most patients with asthma may have eosinophils either in their bloodstream or in their airway at some time during their disease course, accurate data are lacking. In approximately $40 \%$ of asthmatics, eosinophils may play a predominant role in the pathobiology of the disease, with a higher prevalence in asthmatics with severe disease [9]. Under inflammatory conditions, including exposure to allergens and irritants, eosinophils mature and differentiate in the bone marrow, egress into blood, and move to target organs including the lung. IL-5, IL-4, and IL-13, which are derived from classic CD4 cells, play a pivotal role in this process [10]. Notably, the cytokines I1-5, IL-3, and granulocyte-macrophage colony-stimulating factor play a key role in eosinophil development and survival, whereas complement $\mathrm{C} 5 \mathrm{a}$, platelet activating factor, eicosanoids (leukotriene B4 and prostaglandin D2), and ligands for CCchemokine receptor 3 (RANTES, MCP-4, and eotaxin 1, 2, and 3) are major chemoattractants for eosinophils [11]. Recently, nonclassic immune cells, including type 2 innate lymphoid cells (ILC2), have also been shown to be a potent source of type 2 cytokines, prompting a shift in terminology from " $\mathrm{T}_{\mathrm{H}} 2$ inflammation" to "type 2 inflammation" [12]. Thus, newer biological agents have been developed to target key pathways involved in type 2 inflammation, namely, drugs blocking IgE, IL-5, and IL-4/13 signaling [2]. Moreover, given the crucial role of IL-5 in eosinophilopoiesis and eosinophil trafficking, $3 \mathrm{mAbs}$ currently target IL-5 (mepolizumab, reslizumab) or IL-5 receptor $\alpha$ (benralizumab). These agents are currently recommended for severe uncontrolled asthma in patients with evidence of eosinophilic inflammation despite high-dose inhaled corticosteroids (ICS) or oral corticosteroids (OCS), patients who require chronic OCS to maintain control of asthma, and patients who experience significant adverse effects with high-dose corticosteroids [13-15]. All 3 anti-IL5 biologics - mepolizumab (humanized $\operatorname{IgG}_{1} \mathrm{mAb}$, dosed at $100 \mathrm{mg}$ subcutaneously every 4 weeks), reslizumab (humanized IgG4 mAb, dosed at $3 \mathrm{mg} / \mathrm{kg}$ intravenously), and benralizumab (humanized afucosylated $\mathrm{IgG}_{1 \mathrm{kappa}} \mathrm{mAb}$, dosed at $30 \mathrm{mg}$ subcutaneously every 4 weeks for 3 doses followed by $30 \mathrm{mg}$ subcutaneously every 8 weeks) - have been shown to reduce the frequency of asthma exacerbations by approximately $32 \%-53 \%, 50 \%-55 \%$, and $28 \%-70 \%$, respectively, in addition to improving symptoms and quality of life and decreasing corticosteroid dependence [13-19]. No OCS-sparing clinical trials have been conducted with reslizumab. However, despite specifically targeting asthmatics with the eosinophilic endotype, anti-IL-5 biologics were unable to completely resolve asthma exacerbations in clinical trials [13-19].

There is modest evidence in clinical trials and long-term follow-up data regarding the nature of these exacerbations to show whether they are eosinophilic or noneosinophilic (neutrophilic or paucigranulocytic). In a small substudy of a clinical trial involving patients treated with mepolizumab, those whose disease remained uncontrolled had persistent sputum eosinophilia ( $>3 \%$ ) despite normalization of blood eosinophils [20]. This may be due to in situ eosinophilopoiesis orchestrated by ILC $2 \mathrm{~s}$, where low-dose mepolizumab is inadequate to control the intensity of eosinophilia [21], or due to autoimmune mechanisms [22], as previously reviewed [23]. In the initial trial of mepolizumab, patients treated with higher doses (750 mg intravenously) experienced no eosinophilic exacerbations; however, there was 1 exacerbation in the treatment group, although this was neutrophilic in nature [24]. Moreover, a review of 250 patients prescribed anti-IL-5 mAbs (mepolizumab and reslizumab) found that $68.8 \%$ had persistent sputum eosinophils ( $>3 \%$ ) despite normalization of blood eosinophils. This was associated with elevated sputum anti-EPX IgG, a marker of localized autoimmune response associated with increased eosinophil activity and suboptimal response to biologics [25]. Benralizumab, which is an afucosylated $\mathrm{mAb}$, enhances binding to Fc $\gamma$ RIIIa expressed on immune cells such as natural killer (NK) cells and facilitates antibody-dependent cell-mediated cytotoxicity (ADCC). Thus, in addition to blocking the IL-5/IL-5R interaction and subsequent downstream signaling, it depletes $\mathrm{IL}-5 \mathrm{R}^{+}$cells via ADCC (including eosinophils, eosinophil progenitors, basophils, and ILC2s) [26]. In a substudy of a clinical trial with benralizumab, significant attenuation of sputum and 
Table 1. Baseline Characteristics of the Cases Described

\begin{tabular}{|c|c|c|c|c|}
\hline & Case 1 & Case 2 & Case 3 & Case 4 \\
\hline Age & 61 & 62 & 61 & 82 \\
\hline Gender & Female & Male & Male & Female \\
\hline ICS dose $\mathrm{e}^{\mathrm{a}, \mathrm{b}}$ & $1000 \mu \mathrm{g}$ & $3000 \mu \mathrm{g}$ & $2000 \mu \mathrm{g}$ & $1000 \mu \mathrm{g}$ \\
\hline OCS dose $e^{\mathrm{a}, \mathrm{c}}$ & $15 \mathrm{mg}$ & $10 \mathrm{mg}$ & $10 \mathrm{mg}$ & $25 \mathrm{mg}$ \\
\hline $\mathrm{FEV}_{1}, \%$ pred $^{\mathrm{a}}$ & $56 \%$ & $28 \%$ & $51 \%$ & $75 \%$ \\
\hline FVC, \%pred ${ }^{\mathrm{a}}$ & $67 \%$ & $59 \%$ & $64 \%$ & $91 \%$ \\
\hline $\mathrm{FEV}_{1} / \mathrm{FVC}^{\mathrm{a}}{ }^{\mathrm{a}}$ & $64 \%$ & $33 \%$ & $60 \%$ & $56.8 \%$ \\
\hline Blood eosinophils, $\times 10^{9} / \mathrm{L}^{\mathrm{a}, \mathrm{d}}$ & 0.2 & 0.3 & 0.2 & 0.1 \\
\hline Sputum total cell count, $\times 10^{6} / \mathrm{g}^{\mathrm{a}}$ & 17.4 & 1.5 & 78.7 & 3.8 \\
\hline Sputum eosinophils, $\%$ a,d & $3.5 \%$ & $58.8 \%$ & $16.5 \%$ & $5.5 \%$ \\
\hline Biologic(s) treatment & Mepolizumab & $\begin{array}{c}\text { Mepolizumab, reslizumab, } \\
\text { benralizumab }\end{array}$ & $\begin{array}{l}\text { Mepolizumab, } \\
\text { benralizumab }\end{array}$ & Benralizumab \\
\hline
\end{tabular}

Abbreviations: ICS, inhaled corticosteroid; OCS, oral corticosteroid.

aefore initiating biologics.

bFluticasone propionate equivalent.

cPrednisone equivalent.

dPeak values.

blood eosinophils was recorded in patients who received the drug [26]. However, inflammatory endotypes are not stable during an exacerbation, where asthmatics with eosinophilic bronchitis can develop neutrophilic bronchitis or worsening of paucigranulocytic asthma [9]. Thus, it is critical that patients taking these biologics undergo thorough investigations, including sputum differential cell counts, to determine the nature of the exacerbation.

\section{Illustrative Case Reports}

\section{Case 1}

A 61-year-old woman had been followed since 2015 for severe eosinophilic asthma, bronchiectasis, and previously treated allergic bronchopulmonary aspergillosis (ABPA). She also had peptic ulcer disease causing chronic dyspepsia despite partial gastrectomy. Given ongoing prednisone (15 mg) requirements in addition to fluticasone propionate $1000 \mu \mathrm{g}$, and salmeterol $200 \mu \mathrm{g}$, she was started on mepolizumab in May 2018, when her peak blood eosinophil count was $0.2 \times 10^{9} / \mathrm{L}$ and her sputum eosinophil percentage was $3.5 \%$. With treatment, she was able to reduce prednisone to $5 \mathrm{mg}$ (necessary to prevent adrenal insufficiency). In November 2018, she experienced significant weight loss with vomiting and increasing cough and sputum. This was initially attributed to her ongoing gastrointestinal disorder, although no abnormalities were detected on endoscopy. Sputum differential cell counts revealed neutrophilic bronchitis (total cell count of $182 \times 10^{6}$ cells/g, $98.8 \%$ neutrophils) with no evidence of eosinophilia. A computed tomography (CT) scan of the chest revealed a right upper lobe cavity $(3.5 \mathrm{~cm})$ containing an irregularly shaped opacity (Figure 1A). Bronchoscopy was macroscopically unremarkable, although Haemophilus influenzae grew in the bronchoalveolar lavage
(BAL) fluid. There was only modest improvement in her symptoms with an appropriate antibiotic course. CT-guided biopsy of the cavity showed necrotizing granulomatous inflammation with fungi consistent with a diagnosis of semi-invasive aspergillosis. Since she was intolerant of voriconazole and itraconazole, she received a 6-week course of isavuconazole, with significant clinical and radiological improvement. Mepolizumab was discontinued.

\section{Case 2}

A 62-year-old man had been followed since 2013 for eosinophilic asthma. CT scans in 2014 revealed several millimetric nodules, predominantly in the upper lobe. Investigations, including BAL, did not yield pathogenic microbial growth or evidence of vasculitis. Owing to persistent sputum eosinophilia (58.8\%) despite prednisone $10 \mathrm{mg}$, fluticasone propionate $3000 \mu \mathrm{g}$, salmeterol $200 \mu \mathrm{g}$ daily, he was treated with anti-IL-5 mAbs between 2014 and 2018. The response to mepolizumab and reslizumab was suboptimal and marked by exacerbations associated with sputum eosinophilia requiring higher doses of OCS. Therapy was then switched to benralizumab. Over 8 months of treatment, prednisone was reduced only modestly (to $7.5 \mathrm{mg}$ ), and the patient continued to cough and expectorate. Therefore, benralizumab was discontinued, leading to an increase in sputum eosinophils $(42 \%)$. Shortly afterward, in order to evaluate him for another biologic, a chest CT scan performed in August 2019 demonstrated several new and larger pulmonary nodules (Figure 1B). Biopsy of the largest lesion $(2.7 \mathrm{~cm}$ in the upper left lobe) showed necrotizing granulomatous inflammation and a positive polymerase chain reaction assay result for Mycobacterium avium intracellulare. The patient is currently receiving azithromycin, rifampin, and ethambutol. His prednisone dose has been increased to $25 \mathrm{mg}$ daily to control ongoing airway eosinophilia. 

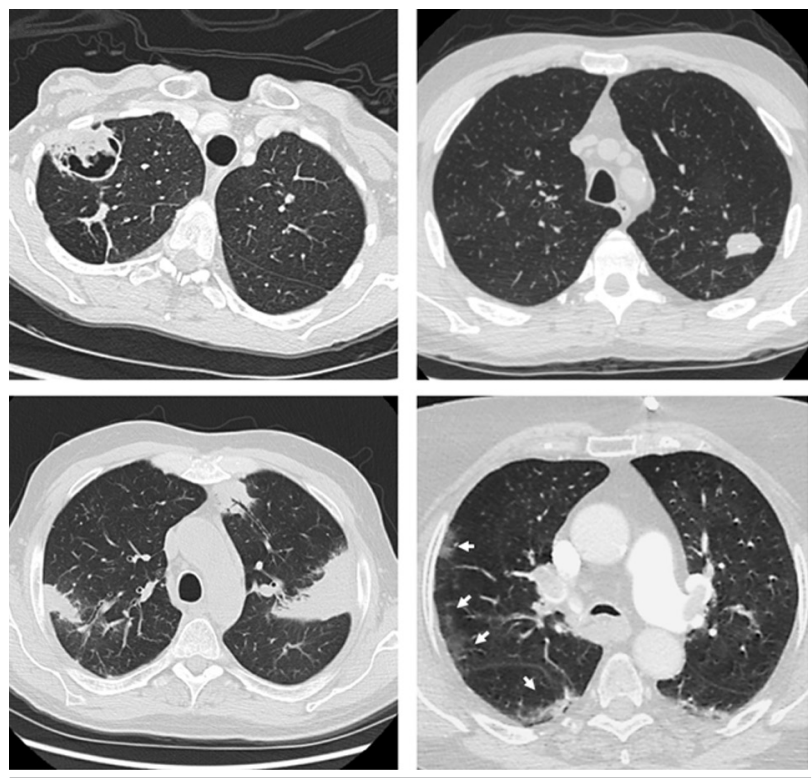

Figure 1. Representative computed tomography (CT) images of the cases presented. A, Case 1: Right upper cavity measuring $3.5 \mathrm{~cm}$. B, Case 2: Left upper lobe nodule measuring $2.7 \mathrm{~cm}$. C, Case 3 : Bilateral patchy upper lobe consolidations. D, Case 4: Peripheral ground glass opacities (arrows).

\section{Case 3}

A 61-year-old man was first seen in 2015 for evaluation of persistent blood eosinophilia (peak $4.2 \times 10^{9} / \mathrm{L}$ ) and sputum eosinophilia (16.5\%) associated with severe asthma. The work-up confirmed a diagnosis of CD20 $0^{+}$Hodgkin lymphoma in a cervical lymph node, which was initially thought to be the most likely cause of eosinophilia. Treatment with doxorubicin, bleomycin, vinblastine, and dacarbazine led to remission of lymphoma and resolution of eosinophilia. However, eosinophilia recurred 2 years later associated with recurrent airway infections, possibly because of acquired hypogammaglobinemia. The patient initiated monthly intravenous immunoglobulin, which effectively controlled the airway infections. Given the persistence of eosinophilia and asthma symptoms despite prednisone $10 \mathrm{mg}$, fluticasone propionate $2000 \mu \mathrm{g}$, and salmeterol $200 \mu \mathrm{g}$ daily, he started mepolizumab in 2017. While receiving this regimen, he experienced an eosinophilic exacerbation (BAL demonstrating $20 \%$ eosinophils) and therefore switched to benralizumab in August 2018. After 6 months of treatment, he developed dyspnea, purulent cough, and weight loss. The blood work-up demonstrated a leukocyte count of $7.9 \times 10^{9} / \mathrm{L}$ with an eosinophil count of $0.1 \times 10^{9} / \mathrm{L}$. Sputum differential cell counts demonstrated intense neutrophilic inflammation (total cell count of $169.1 \times 10^{6} \mathrm{cells} / \mathrm{g}, 96.8 \%$ neutrophils) with no eosinophilia. A chest CT scan demonstrated extensive predominantly peripheral patchy consolidations on both upper lobes (Figure 1C). Initial bronchoscopy did not reveal any causative organisms, alveolar hemorrhage, or malignant cells. A biopsy of lung tissue revealed bronchocentric lymphocytes, neutrophils, and occasional giant cells. Shortly afterward, the patient was admitted to the intensive care unit for septic shock, where a repeat BAL demonstrated Streptococcus pneumoniae and Pseudomonas aeruginosa. He is now recovering on intravenous antibiotics and is on a tapering dose of prednisone (currently $15 \mathrm{mg}$ daily). Benralizumab has been discontinued, and he is waiting for reslizumab to be approved by his insurance company in order to facilitate further prednisone tapering.

Table 2. Characteristics at the Time of Infective Exacerbation While on Biologics

\begin{tabular}{|c|c|c|c|c|}
\hline & Case 1 & Case 2 & Case 3 & Case 4 \\
\hline ICS dose $\mathrm{e}^{\mathrm{a}}$ & $1000 \mu \mathrm{g}$ & $2000 \mu \mathrm{g}$ & $2000 \mu \mathrm{g}$ & $1000 \mu \mathrm{g}$ \\
\hline OCS dose $\mathrm{b}^{\mathrm{b}}$ & $5 \mathrm{mg}$ & $15 \mathrm{mg}$ & $0 \mathrm{mg}$ & $25 \mathrm{mg}$ \\
\hline $\mathrm{FEV}_{1}, \%$ pred & $53 \%$ & $27 \%$ & $77 \%$ & $67 \%$ \\
\hline FVC, \%pred & $68 \%$ & $55 \%$ & $84 \%$ & $85 \%$ \\
\hline $\mathrm{FEV}_{1} / \mathrm{FVC}_{0}$ & $60 \%$ & $38 \%$ & $64 \%$ & $55 \%$ \\
\hline Blood eosinophils, $\times 10^{9} / \mathrm{L}$ & 0.0 & 0.3 & 0.0 & 0.0 \\
\hline Sputum total cell count, $\times 10^{6} / \mathrm{g}$ & 55.5 & 11.1 & 148.5 & NA \\
\hline Sputum neutrophils, $\%$ & 93.3 & 36.8 & 97.8 & NA \\
\hline Sputum eosinophils, $\%$ & $0.3 \%$ & $42.0 \%$ & $0 \%$ & NA \\
\hline Biologic during exacerbation & Mepolizumab & Benralizumab & Benralizumab & Benralizumab \\
\hline Causative organism(s) & $\begin{array}{l}\text { Aspergillus } \\
\text { fumigatus }\end{array}$ & $\begin{array}{c}\text { Mycobacterium } \\
\text { avium-intracellulare }\end{array}$ & $\begin{array}{c}\text { Streptococcus } \\
\text { pneumoniae, } \\
\text { Pseudomonas aeruginosa }\end{array}$ & $\begin{array}{c}\text { Pneumocystis } \\
\text { jiroveci }\end{array}$ \\
\hline Time to infection in months ${ }^{c}$ & 6 & $60(8)$ & $18(6)$ & 6 \\
\hline
\end{tabular}

Abbreviations: ICS, inhaled corticosteroid; NA, not applied; OCS, oral corticosteroid.

aFluticasone propionate equivalent.

bPrednisone equivalent.

'From initiation of first biologic; if multiple biologics were used, time to infection from initiation of the last biologic is listed in brackets. 


\section{Case 4}

An 82-year-old woman was diagnosed with severe eosinophilic asthma (1 severe exacerbation during the previous 6 months) despite being treated with deflazacort $30 \mathrm{mg}$, fluticasone furoate $200 \mu \mathrm{g}$, vilanterol $25 \mu \mathrm{g}$, tiotropium, and long-term azithromycin. Given the severity of her disease, the patient was started on benralizumab in August 2019. Nevertheless, she experienced 2 severe exacerbations, both associated with normal blood eosinophils, with one requiring hospital admission in March 2020. Given the lack of improvement despite high doses of salbutamol and methylprednisolone, we performed a chest CT scan, which demonstrated peripheral ground glass opacities (Figure 1D). Subsequent BAL revealed a normal eosinophil count but elevated neutrophils (1\% eosinophils, 67\% neutrophils); culture of BAL fluid revealed Pneumocystis jiroveci. The patient was not receiving immunosuppressive therapy and her CD4 lymphocyte count was normal. She was treated with trimethoprim-sulfamethoxazole, which led to a significant improvement in her clinical condition.

\section{Eosinophils, IL-5, and Host Defense}

We present 4 patients with severe eosinophilic asthma who developed atypical airway infections while being treated with biologics targeting the IL-5 pathway. In 3 of the 4 patients, the asthma exacerbations were not associated with eosinophilia. The second patient's exacerbation was eosinophilic, as he was not receiving anti-IL-5 therapies and the infection was visible on CT imaging. It is possible that this was gradual progression of a nontubercular mycobacterial infection that he had had for the previous few years. All patients were well-characterized as an eosinophilic endotype, and, given that there was no evidence of eosinophilic inflammation after treatment, we hypothesized that an increase in susceptibility to infections may be mediated by depletion of eosinophils or alteration of immunological pathways in vulnerable hosts. The risk of airway infection may have increased because all of the patients were receiving oral and high-dose inhaled corticosteroids.

The role of eosinophils against helminths is well known; however, eosinophils may also play a role against viral, bacterial, and fungal organisms [6,7,27,28]. Eosinophils may participate in host defense against other organisms and are capable of phagocytosing bacteria, yeasts [29], and parasites [30]. Increased eosinophil migration and activation is observed with both gram-positive and gram-negative bacteria. When activated, eosinophils degranulate and release cationic proteins, such as eosinophilic cationic protein, which can permeabilize bacterial cell membranes [31]. Other killing mechanisms observed include release of RNase [32], DNA traps [33], and production of superoxide species [34]. Eosinophils can also cause a dose-dependent reduction in the infectivity of respiratory syncytial virus by releasing eosinophil-derived neurotoxin [27]. Moreover, eosinophils may act as scavengers with the ability to capture and reduce the infectivity of viruses. However, eosinophils from severe asthmatics are noted to be defective and have a reduced capacity to bind viruses, thus potentially leading to increased viral load [35]. In murine models, eosinophil deficiency was associated with decreased clearance of Aspergillus fumigatus and increased detection of germinating organisms in the lung, independently of neutrophils [36]. However, the association between this finding and the eosinophilia seen in ABPA remains unclear.

IL-5 is a key cytokine that plays a role in differentiation, proliferation, and trafficking of eosinophils. The IL-5 receptor is expressed on eosinophils, basophils, and ILC2 [12]. Under inflammatory conditions, the IL-5 receptor can also be expressed on other inflammatory cells, particularly neutrophils. Indeed, in mouse models, Gorski et al [37] demonstrated that IL-5 receptor expression on neutrophils was increased after influenza A infection. In this study, ILC2derived IL-5 was involved in optimal recovery of influenza A virus by dampening the inflammatory effector function of neutrophils in inflamed lungs. Airway epithelial cells were also recently reported to express functional IL-5 receptor [38]. Thus, blocking IL-5 pathways (by all 3 anti-IL-5 mAbs) or apoptosis of cells that express IL-5R by antibody-dependent cytotoxicity (benralizumab) may potentially impair the innate immune response. Moreover, the IL-5 pathway is important in adaptive immune responses. The IL-5/IL-5R interaction contributes to the maturation of B cells undergoing class switch recombination, which results in production of IgG1 [39]. In murine models, overexpression of IL-5 significantly increases antibody production [40], while IL-5R $\alpha$ chain-deficient mice have reduced levels of immunoglobulin, in particular IgG and IgA, which are crucial for mucosal immunity [41-43].

While there is evidence supporting the role of eosinophils in host defense against all types of microbes in laboratory and murine studies, there is insufficient evidence in humans. Complete lack of eosinophils in humans does not appear to be associated with significant adverse events [44]. Moreover, eosinophil count was poorly correlated with infection and sepsis among critically ill patients [45], and all clinical trials evaluating antieosinophil biologics in asthmatics found that suppression of eosinophils did not correlate with an increased risk for infection $[3-5,46]$. However, randomized controlled clinical trials are underpowered to detect rare events. Thus, while the airway infections that we report may be coincidental, it is important to consider them as potential causes in patients who experience noneosinophilic exacerbations. It is intriguing that 3 of the 4 patients were taking benralizumab. It is possible that the mechanistic and structural differences between benralizumab and the other anti-IL-5 mAbs may contribute to this phenomenon, as elaborated on in the next section.

\section{Benralizumab and Airway Infections}

Although mepolizumab, reslizumab, and benralizumab all target the IL-5 pathway, benralizumab does so by binding the IL-5R $\alpha$ chain located on the surface of eosinophils as opposed to IL-5 itself [47]. Unlike mepolizumab and reslizumab, benralizumab is an afucosylated humanized $\operatorname{IgG}_{1 \kappa}$ agent that facilitates interaction with CD16 (Fc $\gamma \mathrm{RIII})$ on natural killer (NK) cells, causing downstream ADCC and, thus, the destruction of IL-5R $\mathrm{R}^{+}$cells $[26,47]$ and the eradication of both mature eosinophils and eosinophil progenitors [26]. 
Mepolizumab can also decrease eosinophil progenitors in local tissues by $30 \%$, although, in contrast with benralizumab [26], it cannot completely abolish them [48]. Moreover, mepolizumab only achieved this effect with the 750-mg intravenous regimen, but not with the approved clinical dose and route $(100 \mathrm{mg}$, subcutaneous) [21]. While direct comparisons between biologics have not been made, there are differences in the magnitudes of the treatment effects of the 3 discussed here [49]. In OCS-dependent patients, benralizumab was associated with a $70 \%$ reduction in exacerbations [13] compared with a 50\%$60 \%$ reduction for other anti-IL-5 mAbs [14]. Regardless, $20 \%$ of patients in the benralizumab clinical trials still remain OCS-dependent or require higher doses to maintain control of asthma [13].

In the multicenter Severe Asthma Research Program, patients with severe asthma were found to have relatively reduced NK cell numbers in BAL fluid, and these were less effective at killing myeloid target cells than those isolated from healthy controls. The presence of corticosteroids further reduces the release of cytotoxic mediators from NK cells [50]. Thus, ineffective ADCC in the context of reduced or dysfunctional NK cells or associated dysfunction of macrophages phagocytosis may contribute to persistent eosinophilia and suboptimal response to benralizumab. However, this was not the case in a recent single-center study that demonstrated infection, and not eosinophils, as the main cause of exacerbations during therapy with benralizumab [51]. Circulating NK cell numbers were reduced and CD16 expression on CD56 ${ }^{\mathrm{dm}} \mathrm{NK}$ cells was low in suboptimal responders; however, evidence of persistent airway eosinophilia was found in only 2 out of 20 suboptimal responders, suggesting that even the reduced number and function of NK cells are sufficient for benralizumab-mediated eosinophil depletion. In fact, sputum and blood eosinophils were completely suppressed in all other patients, irrespective of whether they were responders or suboptimal responders. This finding is in direct contrast with those reported for the other anti-IL-5 biologics, where the main cause of treatment failure can be attributed to suboptimal eosinophil suppression - as witnessed in this study - and with data from other mechanistic studies of anti-IL-5 biologic failures [25,52]. While infective exacerbations can occur while being treated with all antiIL5 biologics, they seem to be more common in a subset of patients with benralizumab for reasons that we do not currently understand. Anti-IL5 biologics, we believe, do not cause infections, but they seem to increase their frequency. This does not seem to be related to eosinophil suppression.

The use of sputum cytology is crucial to our understanding of the nature of the exacerbation and for directing subsequent optimal management. The absence of this approach may have contributed to inadvertent underreporting of infectious adverse events in large clinical trials. Post hoc analysis of the BORA extension trial reveals respiratory infections (including both upper and lower respiratory tract infections) in $22 \%$ of patients over the 1-year follow-up period (351 out of 1576) [3]. Nevertheless, this may still be underestimated in the BORA extension study, as asthma exacerbations were reported in 823 (52\%) patients with no further sputum-based information on the characteristics of these exacerbations. As illustrated by the cases in this review, infective exacerbations may be completely indistinguishable from eosinophilic exacerbations without sputum analysis. Moreover, a number of these "asthma" exacerbations in clinical trials may have been mislabeled and are actually infective in nature.

In mechanistic terms, it is still unclear how benralizumab contributes to infective exacerbations, how it potentiates infections in a susceptible host, and how it affects NK cell number and function. Perhaps benralizumab-induced ADCC is not specific to the eosinophil cell lineage. It has yet to be determined whether the ADCC of other the cells that express IL-5 (basophils, neutrophils [37], B lymphocytes [39], and epithelial cells [38]) play a role in benralizumab-associated airway infections.

\section{Advances in Sputum Measurement for Identifying Exacerbations}

Blood eosinophil counts have limited utility in the assessment of the nature of exacerbations of severe asthma that occur while patients are being treated with antieosinophilic biologics. There is discordance between blood and sputum eosinophils in uncontrolled asthma [53,54], particularly in OCS-dependent patients [55]. While raised blood eosinophils $(>400 / \mu \mathrm{L})$ are usually associated with airway eosinophilia, the converse may not always be true. In other words, patients with raised sputum eosinophilia may have normal blood eosinophil counts. This correlation is even weaker in the case of exacerbations during treatment with antieosinophil biologics. Most exacerbations associated with sputum eosinophilia may have normal blood eosinophil counts, suggesting that sputum eosinophil counts are superior to blood eosinophil counts for monitoring of patients during therapy with antieosinophil biologics [22,56,57].

In fact, use of sputum cytology to assess airway inflammation has been a pivotal part of the clinical management of patients with complex airway disease. The method of sputum collection is well described and standardized [58,59]. Sputum cellular indices are reproducible, reliable [58], and responsive to change in anti-inflammatory treatments [60]. Using a sputum strategy to guide treatment has been shown to lower the risk ratio of asthma exacerbations by $49 \%$ compared with clinical guidelines [61]. It also helps to increase the corticosteroid dose in exacerbations associated with eosinophilic bronchitis (presence of sputum eosinophils $>3 \%$ or evidence of free eosinophil granules [62]). More importantly, it limits the use of corticosteroids in exacerbations associated with noneosinophilic bronchitis and enables antibiotics to be prescribed instead when exacerbations are associated with neutrophilic bronchitis $[9,63]$. The finding of an increased total cell count and neutrophils $>65 \%$ in sputum [62] is indicative of airway infection. Furthermore, deep sequencing and extended culture of sputum plugs allows for identification of bacterial species, which otherwise go unidentified in routine culture. Assessment of sputum also identifies patients with a paucigranulocytic endotype, ie, absence of airway inflammation, and indicates that other factors, such as airway hyperresponsiveness, may underlie the increase in asthma symptoms.

Recently, sputum measurements have moved beyond simple cell counts. Reports from various laboratories throughout the 
world have revealed successful measurement of a number of fluid-phase mediators that include but are not limited to cytokines, growth factors, chemokines (comprehensive list reviewed by Kelly et al [64]), and inflammatory mediators (eg, eosinophil peroxidase [65] and myeloperoxidase [66], immunoglobulins [67], and exosomes [68]) in processed cellfree supernatants. Sputum cells have been further used to assess ex vivo inflammatory events and identify rare cell populations (such as ILC2s and progenitors [69]). Microbiome [70] and gene signatures [71] are associated with various disease populations and indices of severity. Cellular and molecular assessment of sputum can therefore increase our understanding of the nature of the exacerbation and the underlying mechanisms and thus optimize clinical management.

\section{Our Recommendations for Management of Exacerbations in Patients Receiving Anti-IL-5 Biologics}

Blood eosinophil count is commonly used when initiating therapy with anti-IL-5 mAbs; however, there are currently no recommendations for monitoring response to therapy [72]. If a patient develops an exacerbation while receiving a biologic, it is critical to assess the nature of the exacerbation and to determine the underlying pathophysiology that may have led to the worsening of symptoms. We recommend spirometry (pre- and postbronchodilator) and sputum differential cell counts along with a complete blood count. Persistent sputum eosinophilia (often with a normal blood eosinophil count) constitutes an inadequate response to an antieosinophilic biologic. Therefore, these exacerbations are treated with a short burst of prednisone, and it is reasonable to consider switching to another biologic. Reslizumab [52] and benralizumab [73] have been shown to be effective in severe eosinophilic asthmatics who have a suboptimal response to mepolizumab. Of course, some patients on benralizumab may respond better to one of the other anti-IL-5 mAbs. While there are anecdotal reports in this sense, we do not have randomized controlled clinical trials to support this hypothesis. Neutrophilic bronchitis indicates underlying infections, and patients are treated with the appropriate antibiotics. We do not discontinue or switch a biologic after the first neutrophilic exacerbation. However, if a patient continues to have recurrent neutrophilic exacerbations or persistent airway infection, we suggest further assessment for susceptibility to infections including high-resolution chest CT to investigate bronchiectasis or pulmonary fibrosis,

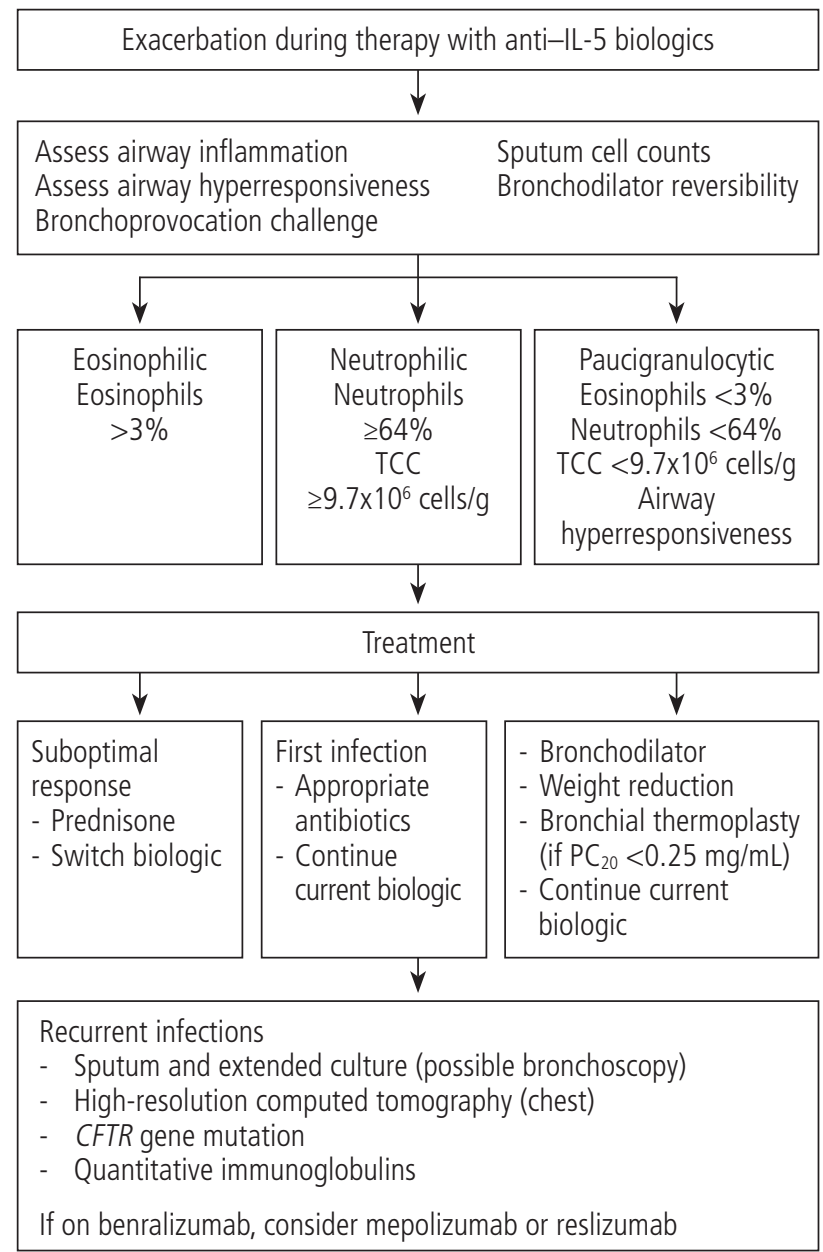

Figure 2. Management of exacerbations during therapy with anti-IL-5 biologics. TCC indicates total cell count.

extended sputum bacterial cultures, CFTR mutation panel, and quantitative immunoglobulins. We do not generally recommend azithromycin in all patients with neutrophilic bronchitis, but rather recommend appropriate antimicrobial therapy guided by culture reports. Bronchoscopy may be performed in patients with radiological abnormalities who are unable to provide a sputum sample. Currently, the relationship between benralizumab and airway infections is an association and does not imply causality. However, it may be prudent to discontinue the biologic (any biologic, not only benralizumab) and observe whether the

Table 3. Differences in Sputum Cellularity During Exacerbations During Therapy With Mepolizumab, Reslizumab, and Benralizumab

\begin{tabular}{|c|c|c|c|}
\hline \multirow[t]{2}{*}{ Nature of Exacerbation } & \multicolumn{2}{|c|}{ Intervention } & \multirow[t]{2}{*}{ Potential Reasons } \\
\hline & $\begin{array}{l}\text { Mepolizumab/ } \\
\text { Reslizumab }\end{array}$ & Benralizumab & \\
\hline Eosinophilic & $90 \%$ & $10 \%$ & $\begin{array}{l}\text { Inadequate dosing/dosing frequency, antidrug antibodies, } \\
\text { autoimmune phenomena }\end{array}$ \\
\hline Noneosinophilic & $10 \%$ & $90 \%$ & $\begin{array}{l}\text { Susceptibility to infections due to ADCC on innate } \\
\text { immunity cells, increased airway hyperresponsiveness }\end{array}$ \\
\hline
\end{tabular}

Abbreviation: ADCC, antibody-dependent cell-mediated cytotoxicity. 
frequency of infection decreases. Patients receiving high doses of prednisone $(>12.5 \mathrm{mg} / \mathrm{d})$ who have recurrent airway infections and associated sputum eosinophilia (ie, patients who are prone to an autoimmune response in the airway [22]) should probably not initiate therapy with mepolizumab, because of the risk of autoimmune worsening of asthma [25]. If therapy is initiated with benralizumab, we recommend very careful monitoring for any indication of worsening of airway infections [51]. In the absence of airway inflammation (normal sputum), the likely mechanism of worsening is smooth muscle hyperresponsiveness, which can be confirmed with either postbronchodilator reversibility or bronchoprovocation challenge. These patients are treated with additional bronchodilators, weight loss, or bronchial thermoplasty (in cases of severe airway hyperresponsiveness with $\mathrm{PC}_{20}<0.25 \mathrm{mg} / \mathrm{mL}$ ), and continuation of current biologic therapy. An approach to management of non-type 2 asthma has previously been reviewed [74]. An algorithm regarding management of exacerbation in patients on anti-IL- 5 biologics is shown in Figure 2.

\section{Conclusion}

In summary, while anti-IL-5 mAbs have bolstered our pharmacological arsenal for treatment of patients with severe asthma, they are not silver bullets. Not only are these therapies limited to patients whose severity and exacerbations are driven primarily by eosinophils, but they may not be able to resolve all eosinophilic exacerbations, particularly when airway eosinophilia is not controlled. Moreover, they would be ineffective for infective exacerbations of asthma. We highlight these limitations with 4 clinical cases involving infective exacerbations while eosinophilic asthma was being treated with anti-IL-5 mAbs. Quantitative sputum cytometry helps to distinguish between eosinophilic and noneosinophilic exacerbations. Most exacerbations in patients receiving mepolizumab or reslizumab are likely to be eosinophilic. In contrast, most exacerbations in patients receiving benralizumab are likely to be neutrophilic (Table 3). Monitoring blood eosinophil count is not very helpful when attempting to identify the nature of an exacerbation. It is important to identify the cellularity of airway secretions during exacerbations (with sputum cytometry when available, or by bronchoscopy if necessary) before considering switching biologics. An eosinophilic exacerbation may respond to an alternate antiIL-5 biologic, while a neutrophilic exacerbation will not.

\section{Funding}

The authors declare that no funding was received for the present study.

\section{Conflicts of Interest}

Dr. Nair is supported by the Frederick E. Hargreave Teva Innovation Chair in Airway Diseases. He has received honoraria from AstraZeneca, Sanofi, Teva, Merck, Novartis, and Equillium, and his university has received research grants from AstraZeneca, Teva, Sanofi, Novartis, BI, and Methapharm. David Dacal Rivas has received grants and/ or fees for talks from Esteve, Boehringer-Ingelheim, GSK,
Novartis, TEVA, Chiesi, and Ferrer. Luis Perez de Llano has received grants and/or fees for consultancy and talks from Novartis, AstraZeneca, GSK, Teva, Boehringer-Ingelheim, Chiesi, Sanofi, Menarini, Mundipharma, and Esteve. Dr. Mukherjee is supported by an investigator award from the Canadian Institutes of Health Research and the Canadian Allergy, Asthma, and Immunology Foundation. She has received grants from Methapharm Specialty Pharmaceuticals and honoraria from AstraZeneca. Dr. Bhalla is supported by the Frederick E. Hargreave fellowship in Airway Diseases. Dr. Zhao and Dr. Ho declare that they have no conflicts of interest.

\section{References}

1. Mukherjee M, Sehmi R, Nair PJWAOJ. Anti-IL5 therapy for asthma and beyond. World Allergy Organ J. 2014;7(1):1.

2. McGregor MC, Krings JG, Nair P, Castro M. Role of Biologics in Asthma. Am J Respir Crit Care Med. 2019;199(4):433-45.

3. Busse WW, Bleecker ER, FitzGerald JM, Ferguson GT, Barker $P_{1}$ Sproule $S$, et al. Long-term safety and efficacy of benralizumab in patients with severe, uncontrolled asthma: 1-year results from the BORA phase 3 extension trial. Lancet Respir Med. 2019;7(1):46-59.

4. Khatri S, Moore W, Gibson PG, Leigh R, Bourdin A, Maspero J, et al. Assessment of the long-term safety of mepolizumab and durability of clinical response in patients with severe eosinophilic asthma. J Allergy Clin Immunol. 2019;143(5):1742-51.

5. Murphy K, Jacobs J, Bjermer L, Fahrenholz JM, Shalit Y, Garin $M$, et al. Long-term Safety and Efficacy of Reslizumab in Patients with Eosinophilic Asthma. J Allergy Clin Immunol Pract. 2017;5(6):1572-81.e1573.

6. Ravin KA, Loy M. The Eosinophil in Infection. Clin Rev Allergy Immunol. 2016:50(2):214-27.

7. Rothenberg ME, Hogan SP. The eosinophil. Annu Rev Immunol. 2006;24:147-74.

8. Lee JJ, Jacobsen EA, McGarry MP, Schleimer RP, Lee NA. Eosinophils in health and disease: the LIAR hypothesis. Clin Exp Allergy. 2010;40(4):563-75.

9. D'Silva L, Hassan N, Wang HY, Kjarsgaard M, Efthimiadis A, Hargreave FE, et al. Heterogeneity of bronchitis in airway diseases in tertiary care clinical practice. Can Respir J. 2011;18(3):144-8.

10. Sanderson CJ. Interleukin-5, eosinophils, and disease. Blood. 1992;79(12):3101-9.

11. Esnault S, Kelly EA. Essential Mechanisms of Differential Activation of Eosinophils by IL-3 Compared to GM-CSF and IL-5. Crit Rev Immunol. 2016;36(5):429-44.

12. Smith SG, Chen $R$, Kjarsgaard $M$, Huang $C$, Oliveria J-P, O'Byrne PM, et al. Increased numbers of activated group 2 innate lymphoid cells in the airways of patients with severe asthma and persistent airway eosinophilia. J Allergy Clin Immunol. 2016;137(1):75-86.e78.

13. Nair P, Wenzel $S$, Rabe KF, Bourdin A, Lugogo NL, Kuna $P$, et al. Oral Glucocorticoid-Sparing Effect of Benralizumab in Severe Asthma. N Engl J Med. 2017;376(25):2448-58.

14. Bel EH, Wenzel SE, Thompson PJ, Prazma CM, Keene ON, Yancey SW, et al. Oral glucocorticoid-sparing effect of mepolizumab in eosinophilic asthma. $N$ Engl J Med. 2014;371(13):1189-97. 
15. Castro M, Zangrilli J, Wechsler ME, Bateman ED, Brusselle GG, Bardin P, et al. Reslizumab for inadequately controlled asthma with elevated blood eosinophil counts: results from two multicentre, parallel, double-blind, randomised, placebocontrolled, phase 3 trials. Lancet Respir Med. 2015;3(5):355-66.

16. Corren J, Weinstein S, Janka L, Zangrilli J, Garin M. Phase 3 Study of Reslizumab in Patients With Poorly Controlled Asthma: Effects Across a Broad Range of Eosinophil Counts. Chest. 2016;150(4):799-810.

17. Ortega $H G$, Liu MC, Pavord ID, Brusselle GG, FitzGerald JM, Chetta $A$, et al. Mepolizumab treatment in patients with severe eosinophilic asthma. N Engl J Med. 2014;371(13):1198-207.

18. FitzGerald JM, Bleecker ER, Nair P, Korn S, Ohta K, Lommatzsch $M$, et al. Benralizumab, an anti-interleukin-5 receptor alpha monoclonal antibody, as add-on treatment for patients with severe, uncontrolled, eosinophilic asthma (CALIMA): a randomised, double-blind, placebo-controlled phase 3 trial. Lancet. 2016;388(10056):2128-41.

19. Bleecker ER, FitzGerald JM, Chanez P, Papi A, Weinstein SF, Barker $P$, et al. Efficacy and safety of benralizumab for patients with severe asthma uncontrolled with high-dosage inhaled corticosteroids and long-acting beta2-agonists (SIROCCO): a randomised, multicentre, placebo-controlled phase 3 trial. Lancet. 2016;388(10056):2115-27.

20. Sehmi R, Smith SG, Kjarsgaard M, Radford K, Boulet L-P, Lemiere $C$, et al. Role of local eosinophilopoietic processes in the development of airway eosinophilia in prednisone-dependent severe asthma. Clin Exp Allergy. 2016;46(6):793-802.

21. Sehmi R, Smith S, Kjarsgaard M, Radford K, Boulet L-P, Lemiere $C$, et al. Role of local eosinophilopoietic processes in the development of airway eosinophilia in prednisone-dependent severe asthma. Clin Exp Allergy. 2016;46(6):793-802.

22. Mukherjee $M$, Bulir DC, Radford K, Kjarsgaard M, Huang CM, Jacobsen EA, et al. Sputum autoantibodies in patients with severe eosinophilic asthma. J Allergy Clin Immunol. 2018;141:1269-79.

23. Bhalla A, Mukherjee M, Nair P. Airway Eosinophilopoietic and Autoimmune Mechanisms of Eosinophilia in Severe Asthma. Immunol Allergy Clin North Am. 2018;38(4):639-54.

24. Nair P, Pizzichini MM, Kjarsgaard M, Inman MD, Efthimiadis $A$, Pizzichini E, et al. Mepolizumab for prednisone-dependent asthma with sputum eosinophilia. N Engl J Med. 2009;360(10):985-93.

25. Mukherjee $M$, Forero DF, Tran $S$, Boulay $M E$, Bertrand $M$, Bhalla $A$, et al. Sub-optimal treatment response to anti-IL-5 monoclonal antibodies in severe eosinophilic asthmatics with airway autoimmune phenomena. Eur Resp J. 2020 (epub).

26. Sehmi R, Lim HF, Mukherjee M, Huang C, Radford K, Newbold $P$, et al. Benralizumab attenuates airway eosinophilia in prednisone-dependent asthma. J Allergy Clin Immunol. 2018;141(4):1529-32 e1528.

27. Shamri R, Xenakis JJ, Spencer LA. Eosinophils in innate immunity: an evolving story. Cell Tissue Res. 2011;343(1):57-83.

28. Percopo CM, Dyer KD, Ochkur SI, Luo JL, Fischer ER, Lee JJ, et al. Activated mouse eosinophils protect against lethal respiratory virus infection. Blood 2014;123(5):743-52.

29. Cline MJ, Hanifin J, Lehrer RI. Phagocytosis by human eosinophils. Blood. 1968;32(6):922-34.

30. Thorne KJ, Glauert AM, Svvennsen RJ, Franks DJP. Phagocytosis and killing of Trypanosoma dionisii by human neutrophils, eosinophils and monocytes. Parasitology. 1979; 79(3):367-79.
31. Lehrer RI, Szklarek D, Barton A, Ganz T, Hamann K, Gleich GJ. Antibacterial properties of eosinophil major basic protein and eosinophil cationic protein. J Immunol. 1989;142(12):4428-34.

32. Nakajima $M$, Hirakata $M$, Nittoh $T$, Ishihara $K$, Ohuchi $K$. Expression and purification of recombinant rat eosinophilassociated ribonucleases, homologues of human eosinophil cationic protein and eosinophil-derived neurotoxin, and their characterization. Int Arch Allergy Immunol. 2001;125(3):241-9.

33. Yousefi S, Gold JA, Andina N, Lee JJ, Kelly AM, Kozlowski E, et al. Catapult-like release of mitochondrial DNA by eosinophils contributes to antibacterial defense. Nat Med. 2008;14(9):949-53.

34. Persson T,Andersson P, Bodelsson M, Laurell M, Malm J, Egesten A. Bactericidal activity of human eosinophilic granulocytes against Escherichia coli. Infect Immun. 2001;69(6):3591-6.

35. Sabogal Piñeros YS, Bal SM, Dijkhuis A, Majoor CJ, Dierdorp BS, Dekker T, et al. Eosinophils capture viruses, a capacity that is defective in asthma. Allergy. 2019;74(10):1898-909.

36. Lilly LM, Scopel M, Nelson MP, Burg AR, Dunaway CW, Steele C. Eosinophil deficiency compromises lung defense against Aspergillus fumigatus. Infect Immun. 2014;82(3):1315-25.

37. Gorski SA, Lawrence MG, Hinkelman A, Spano MM, Steinke JW, Borish $\mathrm{L}$, et al. Expression of IL-5 receptor alpha by murine and human lung neutrophils. PloS One. 2019;14(8):e0221113.

38. Barretto KT, Brockman-Schneider RA, Kuipers I, Basnet $S$, Bochkov YA, Altman MC, et al. Human airway epithelial cells express a functional IL-5 receptor. Allergy. 2020.

39. Horikawa K, Takatsu K. Interleukin-5 regulates genes involved in B-cell terminal maturation. Immunology. 2006;118(4):497-508.

40. Tominaga A, Takaki S, Koyama N, Katoh S, Matsumoto R, Migita $\mathrm{M}$, et al. Transgenic mice expressing a B cell growth and differentiation factor gene (interleukin 5) develop eosinophilia and autoantibody production. J Exp Med. 1991;173(2):429-37.

41. Emslie D, D'Costa K, Hasbold J, Metcalf D, Takatsu K, Hodgkin $\mathrm{PO}$, et al. Oct2 enhances antibody-secreting cell differentiation through regulation of IL-5 receptor alpha chain expression on activated B cells. J Exp Med. 2008;205(2):409-21.

42. Moon BG, Takaki S, Miyake K, Takatsu K. The role of IL-5 for mature B-1 cells in homeostatic proliferation, cell survival, and Ig production. J Immunol. 2004;172(10):6020-9.

43. Hiroi T, Yanagita M, lijima H, Iwatani K, Yoshida T, Takatsu $K$, et al. Deficiency of IL-5 receptor alpha-chain selectively influences the development of the common mucosal immune system independent IgA-producing B-1 cell in mucosaassociated tissues. J Immunol. 1999;162(2):821-8.

44. Gleich GJ, Klion AD, Lee JJ, Weller PF. The consequences of not having eosinophils. Allergy. 2013;68(7):829-35.

45. Smithson A, Perelló R, Nicolas J-M. Is eosinopenia a reliable marker of sepsis? 2009;13(3):409.

46. Lugogo N, Domingo C, Chanez P, Leigh R, Gilson MJ, Price RG, et al. Long-term efficacy and safety of mepolizumab in patients with severe eosinophilic asthma: a multi-center, open-label, phase Illb study. Clin Ther. 2016;38(9):2058-70. e2051.

47. Kolbeck R, Kozhich A, Koike M, Peng L, Andersson CK, Damschroder MM, et al. MEDI-563, a humanized anti-IL-5 receptor alpha mAb with enhanced antibody-dependent cell-mediated cytotoxicity function. J Allergy Clin Immunol. 2010;125(6):1344-53 e1342.

48. Menzies-Gow A, Flood-Page P, Sehmi R, Burman J, Hamid Q, Robinson DS, et al. Anti-IL-5 (mepolizumab) therapy induces 
bone marrow eosinophil maturational arrest and decreases eosinophil progenitors in the bronchial mucosa of atopic asthmatics. J Allergy Clin Immunol. 2003;111(4):714-9.

49. Agache I, Beltran J,Akdis C,Akdis M, Canelo-Aybar C, Canonica $\mathrm{GW}$, et al. Efficacy and safety of treatment with biologicals (benralizumab, dupilumab, mepolizumab, omalizumab and reslizumab) for severe eosinophilic asthma. A systematic review for the EAACI Guidelines-recommendations on the use of biologicals in severe asthma. Allergy. 2020;75(5):1023-42.

50. Duvall MG, Barnig C, Cernadas M, Ricklefs I, Krishnamoorthy N, Grossman NL, et al. Natural killer cell-mediated inflammation resolution is disabled in severe asthma. Sci Immunol. 2017;2(9):eaam5446.

51. Poznanski SM, Mukherjee M, Zhao N. Asthma exacerbations on benralizumab are largely non-eosinophilic. Allergy (under revision). 2020.

52. Mukherjee M, Aleman Paramo F, Kjarsgaard M, Salter B, Nair G, LaVigne N, et al. Weight-adjusted Intravenous Reslizumab in Severe Asthma with Inadequate Response to Fixed-Dose Subcutaneous Mepolizumab. Am J Respir Crit Care Med. 2018; 197(1):38-46.

53. Hastie AT, Moore WC, Li H, Rector BM, Ortega VE, Pascual RM, et al. Biomarker surrogates do not accurately predict sputum eosinophil and neutrophil percentages in asthmatic subjects. J Allergy Clin Immunol. 2013;132(1):72-80.

54. Schleich FN, Chevremont A, Paulus V, Henket M, Manise $M$, Seidel L, et al. Importance of concomitant local and systemic eosinophilia in uncontrolled asthma. Eur Respir J. 2014;44(1):97-108.

55. Mukherjee M, Nair P. Blood or sputum eosinophils to guide asthma therapy? Lancet Respir Med. 2015;3(11):824-5.

56. Mukherjee M, Lim HF, Thomas S, Miller D, Kjarsgaard M, Tan $B$, et al. Airway autoimmune responses in severe eosinophilic asthma following low-dose Mepolizumab therapy. Allergy Asthma Clin Immunol. 2017;13:2.

57. Ojanguren I, Chaboillez S, Lemiere C. Low blood eosinophil counts are not always a reliable marker of clinical response to mepolizumab in severe asthma. J Allergy Clin Immunol Pract. 2018;6(6):2151-3.

58. Pizzichini $E$, Pizzichini $M$, Efthimiadis $A$, Hargreave $F$, Dolovich J. Measurement of inflammatory indices in induced sputum: effects of selection of sputum to minimize salivary contamination. Eur Resp J. 1996;9(6):1174-80.

59. Djukanović R, Sterk PJ, Fahy JV, Hargreave FE. Standardised methodology of sputum induction and processing. Eur Respir J Suppl. 2002;37:1s-2s.

60. Pizzichini MM, Pizzichini E, Clelland L, Efthimiadis A, Mahony J, Dolovich J, et al. Sputum in severe exacerbations of asthma: kinetics of inflammatory indices after prednisone treatment. Am J Respir Crit Care Med. 1997;155(5):1501-8.

61. Jayaram L, Pizzichini MM, Cook RJ, Boulet $L P$, Lemière $C$, Pizzichini $E$, et al. Determining asthma treatment by monitoring sputum cell counts: effect on exacerbations. Eur Resp J. 2006;27(3):483-94.

62. Belda J, Leigh R, Parameswaran K, O'Byrne PM, Sears MR, Hargreave FE. Induced Sputum Cell Counts in Healthy Adults. Am J Respir Crit Care Med. 2000;161(2):475-8.
63. Nair P, Hargreave FE. Measuring bronchitis in airway diseases: clinical implementation and application: Airway hyperresponsiveness in asthma: its measurement and clinical significance. Chest. 2010;138(2 Suppl):38S-43S.

64. Hamid Q, Kelly MM, Linden M, Kelly MM, Linden M, Louis $R$, et al. Methods of sputum processing for cell counts, immunocytochemistry and in situ hybridisation. Eur Resp J. 2002;20(37 suppl):19s-23s.

65. Nair P, Ochkur SI, Protheroe C, Radford K, Efthimiadis A, Lee $N A$, et al. Eosinophil peroxidase in sputum represents a unique biomarker of airway eosinophilia. Allergy. 2013;68(9):1177-84.

66. Wolfe MG, Zhang Q, Hui C, Radford K, Nair P, Brennan JD. Development of a functional point-of-need diagnostic for myeloperoxidase detection to identify neutrophilic bronchitis. Analyst. 2016;141(23):6438-43.

67. HoTN,Al-SelahiE, Huang C.Sputumandserumimmunoglobulins in patients with asthma and recurrent neutrophilic bronchitis. J Allergy Clin Immunol. 2019;143(2):AB227.

68. Sánchez-Vidaurre S, Eldh M, Larssen P, Daham K, MartinezBravo MJ, Dahlén $S E$, et al. RNA-containing exosomes in induced sputum of asthmatic patients. J Allergy Clin Immunol. 2017;140(5):1459-61.e1452.

69. Smith SG, Chen R, Kjarsgaard M, Huang C, Oliveria JP, O'Byrne $P M$, et al. Increased numbers of activated group 2 innate lymphoid cells in the airways of patients with severe asthma and persistent airway eosinophilia. J Allergy Clin Immunol. 2016;137(1):75-86 e78.

70. Taylor SL, Leong LEX, Choo JM, Wesselingh S, Yang IA, Upham JW, et al. Inflammatory phenotypes in patients with severe asthma are associated with distinct airway microbiology. J Allergy Clinical Immunol. 2018;141(1):94-103.e115.

71. Fricker $M$, Gibson PG, Powell $H$, Simpson JL, Yang IA, Upham JW, et al. A sputum 6-gene signature predicts future exacerbations of poorly controlled asthma. J Allergy Clin Immunol. 2019;144(1):51-60.e11.

72. Buhl R, Humbert M, Bjermer L, Chanez P, Heaney LG, Pavord I, et al. Severe eosinophilic asthma: a roadmap to consensus. Eur Resp J. 2017;49(5):1700634.

73. Kavanagh J, Roxas C, Green L. S53 Response to benralizumab after sub-optimal response to mepolizumab in severe eosinophilic asthma. Thorax. 2019;74(Suppl 2):A36-A37.

74. Sze E, Bhalla A, Nair P. Mechanisms and therapeutic strategies for non-T2 asthma. Allergy. 2020;75(2):311-25. Manuscript received June 15, 2020; accepted for
publication June 22, 2020 .

\section{- Parameswaran Nair}

Firestone Institute for Respiratory Health

St Joseph's Healthcare Hamilton

50 Charlton Avenue East

Hamilton, Ontario, L8N 4A6, Canada

E-mail: parames@mcmaster.ca 